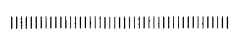

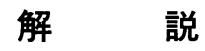

||||||||||||||||||||||||||||||||||||||||||||

\section{Agrochemistry and Biology Series}

\section{海産無脊椎動物の付着・着底・変態に関わる \\ ケミカルシグナルとその応用}

渡辺修治, 衛藤英男

静岡大学農学部応用生物化学科

(平成 7 年 11 月 20 日受理)

\title{
Chemical Signals Involved in Attachment, Settlement, and Metamorphosis of Marine Invertebrate, and Their Application on Marine Sessile Organisms
}

\author{
Naoharu Watanabe and Hideo ETOH \\ Department of Applied Biological Chemistry, Faculty of Agriculture, \\ Shizuoka University, Ohya, Shizuoka 422, Japan
}

\section{はじめに}

多くの海産無脊椎動物は受精, 発生後, 海中で浮遊期間 を送り，ある一定の時期に達すると着底し，底生生活に適 した形態へと変態し底生生活に入る.着底・変態後でも能 動的に移動できるものと，着底した場所から移動せずにそ こで一生を終えるものがある．後者にとって幼生の浮遊期 間は, その種の保存, 勢力拡大にとってたいへん重要であ る. また浮遊期から底生生活に移る際, より生存に適した 場所を認識して着底することも重要である。この期間に浮 遊幼生は何らかの化学物質を認識することによって着底・ 変態を引き起こすと考えられ, 海産無脊椎動物幼生の着 底・変態誘導因子やメカニズムの解明研究がす寸められて きた。

一方, 海洋の岩礁, 人工構築物, 船底などに付着してそ の機能を大きく低下させるなどの被害を及ぼすことで知ら れている海洋污損生物（フジツボ，ムラサキイガイなどの 動物種, 海藻などの植物種など）の防除を目的として, と くにムラサキイガイの特有な行動様式を利用した新しい防 除法, 防污物質の開発研究が展開されている. また人工魚 礁への藻類の付着促進, 磯やけ防止, テトラポットなどの 早期安定化などへの付着誘引物質の応用の可能性も検討さ れている．第 1 章では海産無脊椎動物幼生の着底・変態誘 導物質の解明研究について, 第 2 章で海洋付着生物の制御 を目的とした新しい観点からの防污物質および付着誘引物 質の探索, 開発研究の現状について紹介する.

\section{1. 海産無脊椎動物幼生の着底・ 変態誘導物質の解明研究}

海産無脊椎動物幼生の着底・変態誘導物質の解明研究に は主として次に紹介する二つの方法がとられている. 第一 は神経伝達物質に対する幼生のレスポンスを観察する方法 である. 第二は浮遊幼生がその棲息圈内に存在する何らか の化学的因子：ケミカルシグナルを認識して着底・変態を 起こすとの考えに基づき, 藻類, 成体や成体の棲管等から 幼生の着底・変態を誘起する物質を探索し, これらを天然 物化学的手法で精製, 単離, 構造決定をする方法である.

\section{1) 神経伝達物質による着底・変態}

脊椎動物と同様な神経伝達システムが海産無脊椎動物に も存在すると仮定して, 多くの研究者が幼生の神経伝達物 質に対する影響を検討している。 その結果, 図 1 に示すよ うな各種の神経伝達物質によって幼生の着底変態が起こる ことが報告されている。これらについては最近, 著者との 共同研究者である Okamoto が詳しく紹介している（未発 表).

神経伝達物質による幼生の変態誘導にはレセプターを介 したメカニズムが提唱されている.たとえば図 $2^{1}$ に示すよ うに, 着底の条件が満たされた（化学物質等の刺激を受け た）力キ幼生の神経末端から dopamine が放出され, これが 神経系にある Integration Center (IC) を刺激することによ つて着底行動が始まる. 着底行動の途中, あるいは着底後 に内因性の epinephrine, norepinephrine 等の物質が放出さ 
れ，アドレナリンレセプターと相互作用して変態が開始さ れる。 ウミウシの一種, Onchidoris bilamellata の幼生から は着底に関係するレセプターの存在が確認されている。ま た, Okamoto および著者ら ${ }^{2}$ は, 管棲多毛類の一種である工 ゾカサネカンザシ Hydroides ezoensis の幼生は DOPAに よって変態が誘導されるが, L-DOPA はその光学異性体で ある D-DOPAよりも強い変態誘導を起こすことから，LDOPA に対するレセプターの存在を示唆している.

\section{2) 天然物起源の着底・变態を誘起する物質}

生態系において海産無脊椎動物の分布は一様ではない。 たとえば管棲多毛類のある種は同種が塊となってコロニー を形成しており，しかもコロニーの外縁部ほど個体の世代 が若くなる傾向がみられる，またアワビやウニなどの栽培 漁業において，浮遊幼生がある種の珪藻が生育している場 所に集中的に付着する現象が観察されている。ムラサキイ ガイ, フジツボ, カンザシゴカイなどの污損生物等の付着 過程では，人工構築物等の基盤に初めはなかなか付着が進 まないが， ある程度微生物が付着すると生物の付着量は急 激に増加するという知見もある.

Pawlik ${ }^{3}$ は管棲多毛類である Phragmatopoma californica の棲管から同幼生の着底・変態を誘起する数種の脂肪酸を 単離した。これに対して Jensen ら ${ }^{4}$ は P. californica の棲管 は幼生の変態を誘導したが，棲管中には Pawlik の報告し た脂肪酸をほとんど含有していないことから，単離された 脂肪酸は微細藻類のコンタミネーションによるもので，棲 管中に含まれる変態誘導物質は別にあると指摘している。

Kitamura ら ${ }^{5}$ は，有節サンゴモの一種である Corallina pilulifera からウ二Pseudocentrotus depressus や Anthocidaris crassispina の幼生の変態を誘導する遊離不飽和脂 肪酸 arachidonic acid (20:4) および icosapentaenoic acid (IPA, 20:5) を単離した.

Taniguchi $ら^{6}$ はウウの一種 Strongylocentrotus nudus, ア ワビの一種 Haliotis discus の幼生の変態を誘導する無節サ ンゴモ Lithophyllum yessoence, 有節サンゴモ Serraticardia maxima, Calliarthron yessoense, 緑藻 Ulvella lens の成分を 分析した結果， 3 種類のハロメタン (dibromomethane, dibromochloromethane, tribromomethane）が共通して含まれ ていることがわかり，市販のハロメタンを用いてそれらの 幼生の変態に対する影響を検討したところ, dibromomethane が S. nudus 幼生の変態を $100 \%$ 誘導したと報告してい る.

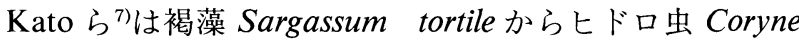
uchidai 幼生の変態誘導物質として $\delta$-tocotrienol を単離し た。また，塚本 ${ }^{8}$ は，ユウレイボヤ Ciona savignyi の成体か ら同幼生の変態誘導物質として urochordamine A, B を, 褐 藻 Sargassum thunbergii からもマボヤ Halocynthia roretzi 幼生の変態誘導物質として diphlorethol, sulfoquinovosyl diacylglycerol を単離した。さらに彼ら ${ }^{9}$ は伊豆半島で採取 した海綿 Jaspis sp.の抽出物から $(Z)$ - および $(E)$-narain を単離構造決定した. 変態誘導活性には陰イオン部分が重 要であり, $(Z)$-体の変態誘導活性が $(E)$-体の 10 倍高いと いう結果を報告している。

Chevolot ら ${ }^{10)}$ は紅藻 Delesseria sanguinea からタテ Pecten maximus 幼生の変態誘導物質として jacaranone を 単離し，その類縁化合物や神経伝達物質を用いて，幼生の 変態に対する影響と化学構造との関係を検討したところ, 天然にある変態誘導物質はキノンやキノン様構造をもって いるとしている.

著者ら ${ }^{11}$ は最近，静岡県浜名湖に生息するエゾカサネカ ンザシ H. ezoensis の群居性に注目して，エゾカサネカンザ シの棲管抽出物から幼生の着底・変態を誘起する化学因子 を検索した。その結果 DHA monoacylglycerol をはじめと する数種の acylglycerol が変態誘導活性に関わっているこ とを明らかにした。

以上の化合物の多くは抗酸化能（酸化反応の上い基質と なりうる）を有すると考之られ興味深い。

\section{3）真の変態に関わるケミカルシグナルを求めて}

著者らはエゾカサネカンザシ幼生を飼育する途上，容器 内での幼生密度が異常に高くなると彼らは互いに集まり大 きな塊を形成し，やがて変態することを観察している。こ のことから，ある密度以上になると幼生がケミカルシグナ ルを放出していることが示唆され，現在この点から真の変 態誘導物質を求めるべく検討している。一方, さきの塚本 ${ }^{12)}$ らはホヤのオタマジャクシ型幼生においてもわれわれと同 様な知見を見いだし，すでに高密度培養液から活性物質の 単離に成功している。 また幼生のライフサイクルを通じた 本化合物の消長も明らかにされ，この物質は発生の初期に すでに存在するというきわめて興味深い事実も明らかにし ている。本稿が読者の目に触れる頃には化学構造も明らか になっていると思われる。

\section{4) 光の 他}

上村ら ${ }^{13)}$ は，カサネカンザシ Hydroides elegans の in situ における付着の様子を検討するために実海域にスライドガ ラスを浸漬し，幼生がよく付着したスライドガラスを得， 幼生の付着状況を詳しく調べた，その結果，幼生がよく付 着しているスライドガラスには原生動物である太陽虫（未 同定）が多く観察され，カサネカンザシ幼生は太陽虫の周 りを旋回した後にスライドガラスに付着して変態すること が観察された。この太陽虫を培養してカサネカンザシ幼生 に添加してその影響を検討したところ，太陽虫無添加では カサネカンザシ幼生は変態しなかったのに対して，添加区 ではほとんどの幼生が変態した。一方，太陽虫のアセトン 抽出物は変態を誘起しなかったことから，太陽虫によるカ サネカンザシ幼生の変態誘導は太陽虫がカサネカンザシに 
接触することで起こると指摘している。

ところで, 海産無脊椎動物幼生の変態時には, 細胞の分 化が劇的に起こっているものと考えられる. 細胞分化の研
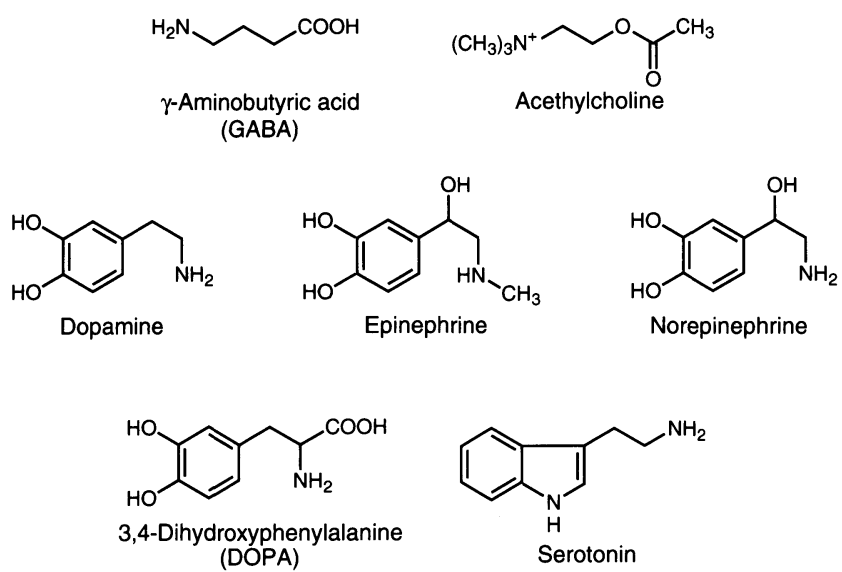

図 1 海産無脊椎動物幼生の着底・変態誘導活性を有 する神経伝達物質

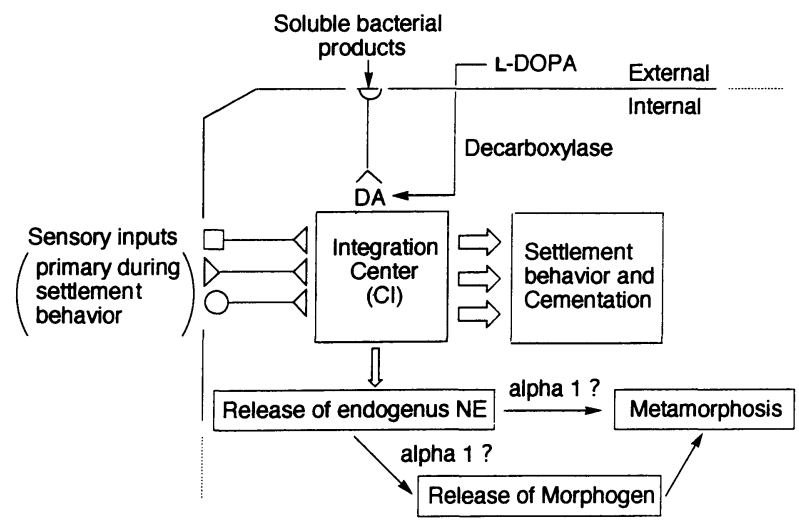

図 2 力キ幼生の着底・変態機構のモデル2)
究はおもに脊椎動物の細胞（とくに癌細胞）を用いて行な われており，細胞分化を誘導する化学因子として活性酸素 類が関与していると指摘する報告がある，また，ウミウシ の一種, Phestilla sibogae の幼生の変態は活性酸素種の $\mathrm{H}_{2} \mathrm{O}_{2}$ によって誘導されたといわれている。これらの活性酸素と 分化・変態誘導に関する研究例, および, 多くの海産無脊 椎動物幼生の着底・変態誘導物質が上述したように抗酸化 能を有する，あるいは酸化に対して良い基質となりうる化 合物である点とを考え合わせると, 酸化-還元系と幼生の着 底，変態との関係に興味がもたれる。

\section{2. ムラサキイガイを用いた防污，付着 誘引物質の探索, 開発研究}

\section{1) ムラサキイガイの付着忌避物質の探索}

フジツボ，ムラサキイガイなどの動物種，海藻などの植 物種は, 海洋の岩礁, 人工構築物, 船底などに付着してそ の機能を大きく低下させるなどの被害を及ぼすことから， 污損生物と呼ばれている。これらの防除対策は実にさまざ まな方法がとられてきた.最近まで用いられていた方法は, 亜酸化銅または有機錫化合物を塗料に混ぜて用いるもので あった.ところが，最近有機錫化合物（たとえば tributyl tinoxide (TBTO) や triphenyl tinoxide (TPT) 化合物など) が海洋に流出し，污染をまねき，さらにこれらが食物連鎖 を経て，具類，魚類に移行した。 その結果，生体への影響 が懸念され，使用が禁止された。このため，これらに替わ る安全な防污剤の開発が急務となっている.

筆者らは，代表的な污損生物の一種であるムラサキイガ イ (Mytilus edulis) を用い，この貝に対する付着忌避物質 （付着生物を殺すことなく付着を忌避させる物質）を，食品 素材または動物の飼料を中心とした植物成分から求める研 究を行なっている.

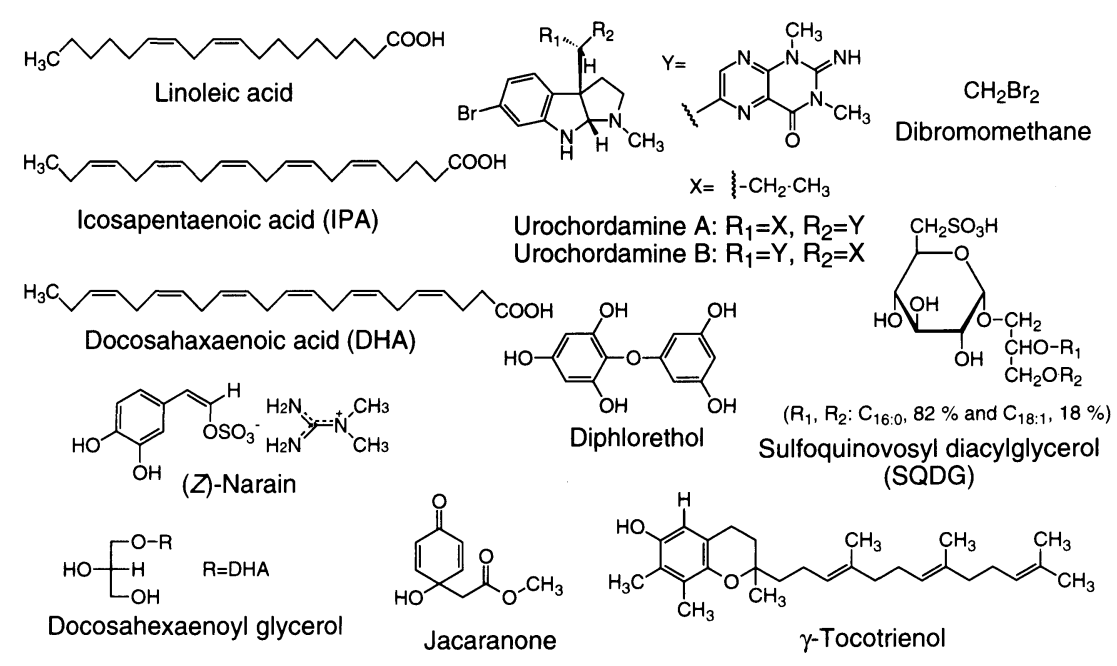

図 3 天然物起源の海産無脊椎動物幼生の着底・変態に関わる物質 
(1) ムラサキイガイを用いる忌避物質検索法

防污活性の検定は，実際の海での効果をみる浸漬試験法 がよいと思われるが，生物検定が長期にわたることや，季 節や海水の状態によって，結果が不安定になるなど問題点 が多い.そこで，活性測定のための生物検定法として，独 自に開発したムラサキイガイを用いる付着忌避活性試験 法 ${ }^{14)}$ を用いている.その方法を簡単に述べる。この貝は，他 の付着生物フジツボなどと異なり, 足 (foot) と呼ばれる器 官で付着位置を検索し，その後，粘着板 (disk)に続く足系 (byssus) と呼ぶ強勒なタンパク質の繊維状の物質を分泌 し, 海水中の基盤に貝殼を固定する. 貝をゴム片で固定し, 海水の流入する水槽内に放置すると，3 時間で十数本の足 系を貝殼の前方に出す。もし前方に貝が嫌がる物質（忌避
物質）があると，図4Bのようにそれを避けて足糸を出す. この性質を利用した方法である。

(2) 付着忌避物質とそれらの強さ

硫酸銅の最少の忌避量をユニット 100 として，現在まで に活性のみられた化合物とそれらの強さを図 $5^{15,16)}$ に示し た. 著者らの発見したなかで，硫酸銅より活性の強い物質 は nicotinamide（1）（ユニット 310), kaempferol 3-O-(2", 6"-di- $O$ - $(E)$ - $p$-coumaryl- $\beta$-D-glucopyranoside (2) (ユニット 230), polydatin 6"-O- $(E)$-p-coumarate (3) （ユニット 190) および rhaponticin 6"-O- $(E)$-p-coumarate（4)（ユニット 180)であった. Nicotinamide は，貝柱の筋肉に対する作用 があることがわかっているが，その他の忌避の機構はわか っていない.

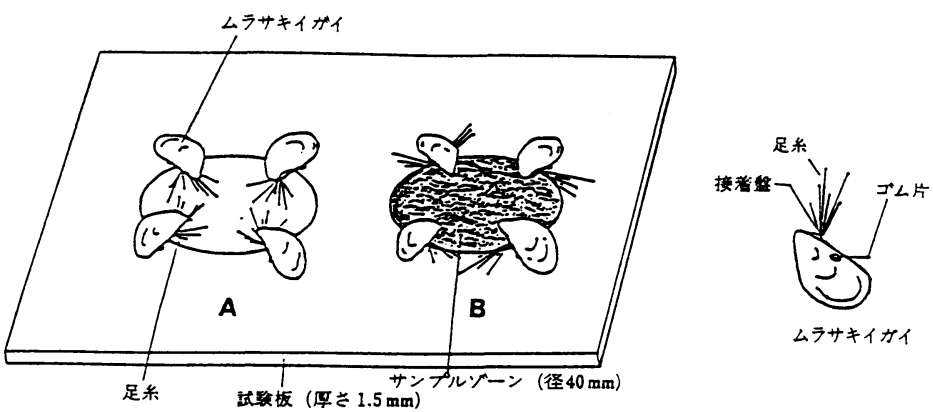

図 4 ムラサキイガイを用いた付着忌避物質検索法 ${ }^{14)}$<smiles>NC(=O)c1cccnc1</smiles>

1

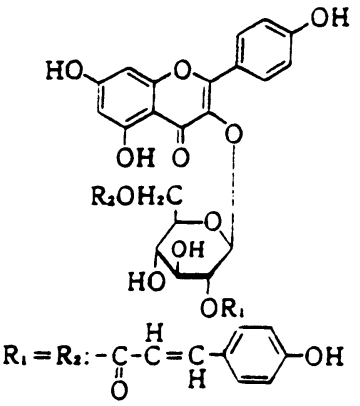

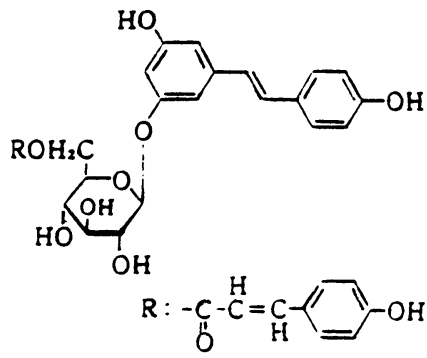

3

2

4

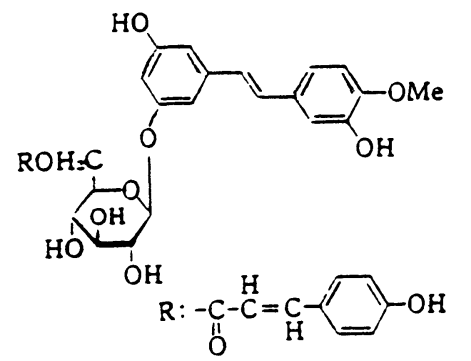

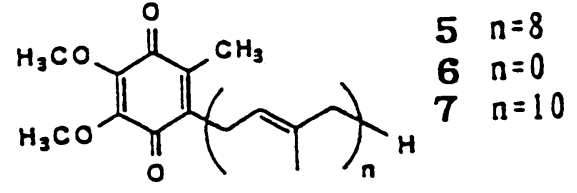

図 5 ムラサキイガイの付着忌避物質 $\left.{ }^{15}, 16\right)$

ユニット $=100 \times \frac{\text { 硫酸銅 }\left(++ \text { を示す最少量, } \mu \mathrm{mol} / \mathrm{cm}^{2}\right)}{\text { サンプル }\left(++ \text { を示す最少量, } \mu \mathrm{mol} / \mathrm{cm}^{2}\right)}$ 
同じ方法で，海洋バイオ清水研では，海洋の生物，微生 物から活性物質の単離を行なっており, ubiquinione $(8,0$, 10） $(5,6,7)$ が硫酸銅と同じ強さを有していると報告して いる.

(3) 付着忌避物質の実用化

忌避活性のみられた物質がすぐに実用化できるかという とそう簡単ではない，海中では，まず微生物の付着（スラ イム）が起き, 次に微細藻類（植物種）の付着，その後ウ ズマキゴカイ，ムラサキイガイ，フジツボ，カキなどの動 物種が付着していく．これらすべての付着を忌避する必要 がある，たとえば，抗生物質は，菌に対しては効果がある が, 藻類や動物種には効果がない. 著者らは，ムラサキイ ガイに対する忌避試験に加えて, 抗菌活性試験（カビの 1 種，Trycophyton mentagrophytes) および藻類に対する防藻 試験を行ない，それらに活性がみられた物質を海水中での 浸漬試験を行ない, 実用化にもっていくことを提案している.

以上の点および価格の点から，現在までに実用化できた 化合物は nonylphenol のみであった.

毒性の問題から, 著者らは炭素, 水素, 酸素から成る有 機化合物に重点をおいて研究してきたが，その他の元素を 有する農薬のなかから安全で, 効果的な化合物がみつけら れる可能性もある．ただ，実際に利用する場合，一つの化 合物のみに防污効果を期待するのではなく，それぞれのス テージにのみ有効な物質を組み合わせて使うなどの方向に 今後進むものと思われる.

\section{2) ムラサキイガイの付着誘引物質の探索}

日本は, 古来より海から海藻や魚類などを食糧資源とし て得てきた．しかしながら，近年人工の増加，資源の乱獲 や海洋污染によって海洋資源の枯渇が䯚念されるようにな ってきた。そのため，人工魚礁と呼ばれる海中構築物を海 中に敷設し，魚類などが安全に繁殖できるような栽培漁業 が盛んとなった，しかし，敷設物としてコンクリート，プ ラスチック，鉄や古タイヤなどを用いた人工魚礁では，実 際に藻類が付着, 繁殖し, 魚礁としての機能を発揮するま でには, 少なくとも 3〜4 年の歳月が必要である.そのため, 魚礁用構築物に初期付着生物である藻類などの付着, 発育 促進作用をもつ物質を塗布して，効果的に海産物を得る試 みが広く行なわれている，それは，魚礁表面に藻類が付着 しやすくするため, 表面を粗にする, 光ファイバーで藻類 の成長に欠かせない太陽光を照射する，魚礁材料表面にあ らかじめ藻類の胞子を付着しておく,などの物理的方法と, 化学物質の叙布により付着生物の付着誘引，発育促進をさ せる, 有用藻類の成長を阻害する雑藻の成長を阻害する, 藻食動物を忌避させる, などの化学的方法に分けられる.

海藻などの増殖促進の研究で発見された化学物質は, (1) 肥料の利用，(2) 金属単体の利用，(3) 植物ホルモンの利 用，(4) ステロイド・高級アルコールの利用，（5）有機酸
およびそれらの誘導体の利用，などに分類される。

著者らは，浸漬試験法により現在まで報告されていない benzoic acid および kojic acidに付着生物の付着誘引効果 を認めた。これらを用いて，ムラサキイガイを用いる簡単 な付着誘引物質検索法の確立を行なった。

(1) ムラサキイガイを用いる付着誘引物質の探索

付着忌避試験に利用していたムラサキイガイを用いる試 験法を一部改良することで, 付着誘引物質の検索に応用し 得るかを検討した，方法は，特殊な厚紙ウェブロンに直径 $4 \mathrm{~cm}$ の内円と, 直径 $7 \mathrm{~cm}$ の外円を描き，それらを 8 等分し て交互にサンプルを塗る. 次に，内円の周りに4個の貝を， それぞれちょうつがい方向を内側にして固定する。 その板 を, 海水が流入する水槽内に 3 時間浸漬した後, 試験板を 取り出し, 貝の足系の数と付着位置を数える。この方法を 図6に示した. 図6Bは，サンプルを塗った部分と塗らない 部分どちらも同じように足糸が出ている。 それに対して， 図6A ではサンプルを塗った部分にのみ足系が出ている. つまり，左に塗った化合物は付着誘引効果があると判定で

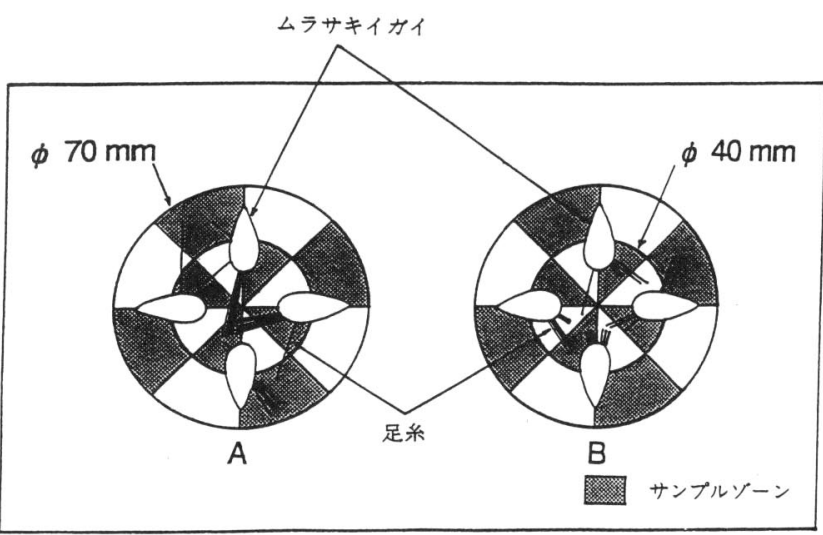

図 6 ムラサキイガイを用いた付着誘引物質検索法<smiles></smiles><smiles>COC(=O)OC</smiles><smiles>CC(C)(C)C1=CC(c2cc(C(C)(C)C)c([O-])c(C(C)(C)C)c2)C=C(C(C)(C)C)C1=O</smiles><smiles>COc1cc(/C=C/C(=O)CC(=O)/C=C/c2ccc(O)c(OC)c2)ccc1O</smiles><smiles>COc1cc(CCC(=O)CC(=O)CCc2ccc(O)c(OC)c2)ccc1O</smiles>

13

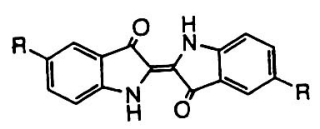<smiles>Cc1c(C)c2c(c(C)c1O)CCC(C)(CCCC(C)(C)C)O2</smiles>

$14: \mathrm{R}=\mathrm{SO}_{3} \mathrm{Na}$

困 7 ムラサキイガイの付着誘引物質 
Table 1 Attaching attractive activity for blue mussel.

\begin{tabular}{lccc}
\hline Compounds & $\begin{array}{c}\text { Sample amount } \\
\left(\mu \mathrm{mol} / \mathrm{cm}^{2}\right)\end{array}$ & $\begin{array}{c}\text { Attaching } \\
(\%)\end{array}$ & Activity \\
\hline BHT & 28 & $77 \pm 8^{\mathrm{a})}$ & $(+)$ \\
& 14 & $76 \pm 19$ & $(-)$ \\
3,5-Di-tert-butyl-4-hydroxyanisole & 28 & $87 \pm 15$ & $(+)$ \\
Galvinoxyl & 14 & $77 \pm 25$ & $(-)$ \\
& 14 & $81 \pm 0$ & $(+)$ \\
Curcumin & 7.0 & $83 \pm 23$ & $(-)$ \\
Curcumin Mg chelate & 3.5 & $87 \pm 9$ & $(+)$ \\
4H-curcumin & 1.0 & $94 \pm 6$ & $(+)$ \\
Indigocarmine & 1.0 & $76 \pm 13$ & $(+)$ \\
$\alpha$-Tocopherol & 1.0 & $89 \pm 2$ & $(+)$ \\
Control & 1.0 & $75 \pm 12$ & $(+)$ \\
\hline
\end{tabular}

a) Standard deviation, number of trials 4-18.

$+:$ attractive activity, $-:$ not attractive activity.

きる。

(2) ムラサキイガイの付着誘引物質 ${ }^{16,17)}$

Kojic acid (8) は塗布量の増加に伴って誘引効果を示し たが，マグネシウムキレートでは，少ない塗布量でも効果 があった。この他，効果が認められた化合物とその活性を 図 7 およびTable 1 に示した。 これらの構造と活性の関係 はまだわからないが, 金属が重要であると考えられる.

海洋バイオ清水研では，スライムの $2 / 3$ の抽出物に弱い 誘引活性を認め, さらに tyrosine および DOPA に活性があ ることを報告している.

\section{おわりに}

海水は海洋生物のケミカルコミニュケーションの媒体で ある。したがって海洋生物のケミカルシグナルの情報伝達 機能は, 哺乳動物の体液を介した生体内での情報伝達機構 と類似していると予測される。海産無脊椎動物幼生の着底, 変態に関わる真のケミカルシグナルの解明が哺乳動物の生 理機能の解明につながる可能性を秘めている.

一方，地球規模の環境問題は，人間からみた一方的な問 題としてとらえないで，地球に住むあらゆる生物との共存 で考えなければならない，海洋污損生物に対する効果的な 防污物質がみつけられれば，人間生活にとっては好都合で あるが，付着生物にとっては住み場所がなくなる．また， そのことによって付着生物に耐性が付けば，さらに多量の 防污剤が必要となる．付着忌避物質と付着誘引物質の両者 をうまく使い分ければ，原子力発電所，火力発電所などの 給水口などの閉鎖采において，付着生物を 1 か所に集め, 付着して欲しくないところには付かないようにし，集めら れた付着生物は別のところで生活してもらうということが 可能となり, 人間と付着生物との地球上での共存が可能に なる。.また，付着誘引物質は，人工魚礁への藻類の付着促 進，磯やけ防止，テトラポットなどの早期安定化など幅広
い用途が考えられる．環境を考えた産業廃棄物の再利用な ど，付着忌避および付着誘引物質の利用の研究が今後ます ます盛んになると思われる。

本稿を通読いただきました東京大学農学部附属水産実験所助 手 岡本 研先生に深謝いたします。

\section{引用 文 献}

1) S. L. Coon, W. K. Fitt \& D. B. Bonar : Mar. Biol. 106, 379 (1990)

2) K. Okamoto, A. Watanabe, N. Watanabe \& K. Sakata: Fish. Sci. 61, 69 (1995)

3) J. R. Pawlik: Mar. Biol. 91, 59 (1986)

4) R. A. Jensen, D. B. Morse, R. L. Petty \& N. Hooker : Mar. Ecol. Prog. Ser. 67, 55 (1990)

5) H. Kitamura, S. Kitahara \& K. Hirayama : Nippon Suisan Gakkaishi 58, 75 (1992)

6) K. Taniguchi, K. Kurata, T. Maruzoi \& M. Suzuki : Fish. Sci. 60, 795 (1994)

7) T. Kato, A. J. Kumanireng, I. Ichinose, Y. Kitahara, Y. Kakinuma, M. Nishihara \& M. Kato : Experientia 31, 433 (1975)

8) 塚本佐知子：化学と生物 31, 701 (1993)

9) S. Tsukamoto, H. Kato, H. Hirota \& N. Fusetani : Tetrahedron Lett. 35, 5873 (1994)

10) L. Chevolot, J. C. Cochard \& J. C. Yvini : Mar. Ecol. Prog. Ser. 74, 83 (1991)

11) 岡本 研 - 井出純次 - 渡邊重夫 ・坂田完三 ・渡辺修治：平 成 7 年度日本水産学会春季大会講演要旨集, p. 300, 1995

12）塚本佐知子：第 9 回海洋生物活性談話会講演プログラム, p. 2,1995

13）上村一雄・布施博之・滝村 修·山岡到保：中国工業技術 試験場報告 No. 38, 9 (1992)

14）伊奈和夫・衛藤英男：化学と生物 28, 132 (1990)

15）伊奈和夫・衛藤英男：化学々生物 30, 249 (1992)

16) 産業科学技術研究開発「高機能化学製品等製造法（海洋生 物活用)」第一期研究，開発評価，平成 6 年 3 月

17) H. Etoh, N. Murayama, N. Watanabe, R. Takasawa, W. Miki \& K. Ina: J. Mar. Biotechnol. 2, 55 (1994) 